\section{Morphological parameters of image processing to characterize primary root emergence in evaluation of tomato seed vigor}

\author{
Gustavo Roberto Fonseca de Oliveira*1 (D), Felipe Kuhn Leão de Salles ${ }^{2}$ \\ Thiago Barbosa Batista ${ }^{1}$ (D, Marcio Souza da Silva ${ }^{3}$ (D), Silvio Moure Cicero ${ }^{3}$ (D), \\ Francisco Guilhien Gomes-Junior ${ }^{3}$
}

ABSTRACT: The use of computational tools has become notable in seed quality control to assist in confirming seed lots of higher potential. Thus, the aim of this study was to use a computational approach to investigate analysis of morphological parameters that characterize primary root emergence in evaluation of tomato seed vigor. For that purpose, five seed lots were analyzed for germination and vigor (seedling emergence and analysis of seedling images). A parallel analysis of primary root emergence was made using computerassisted imaging; the images recorded as germination proceeded were processed with the Image ${ }^{\circledR}$ software to obtain aspect ratio and seed area parameters. Vigor differences among tomato seed lots can be identified based on primary root emergence, and computer image processing based on aspect ratio proves to be an efficient procedure to characterize emergence of the primary root in evaluation of tomato seed vigor.

Index terms: Solanum lycopersicum, physiological potential, aspect ratio, computational tools.

Parâmetros morfológicos de processamento de imagens para caracterização da emergência da raiz primária na avaliação do vigor de sementes de tomate

RESUMO: A inclusão do uso de ferramentas computacionais no controle da qualidade de sementes tem-se destacado com o intuito de auxiliar em maior assertividade na caracterização de lotes de maior potencial. Assim, o objetivo deste estudo foi investigar por meio de uma abordagem computacional a análise de parâmetros morfológicos que caracterizem a emergência da raiz primária na avaliação do vigor de sementes de tomate. Para isso, cinco lotes de sementes foram analisados quanto a sua germinação e vigor (emergência de plântulas e análise de imagens de plântulas). Em paralelo, a emergência da raiz primária foi analisada utilizando visão computacional assistida; as imagens registradas durante o progresso de germinação foram processadas com o software ImageJ ${ }^{\circledR}$ para obtenção dos parâmetros de relação de aspecto e área da semente. As diferenças de vigor entre lotes de sementes de tomate podem ser identificadas com base na emergência da raiz primária e o processamento computacional das imagens baseado na relação de aspecto apresenta-se como um procedimento eficiente para a caracterização da emergência da raiz primária na avaliação do vigor de sementes de tomate.

Termos para indexação: Solanum lycopersicum, potencial fisiológico, relação de aspecto, ferramentas computacionais.
Journal of Seed Science, v.43, e202143005, 2021

http://dx.doi.org/10.1590/ 2317-1545v43245215
$*$ Corresponding author
E-mail: grfonseca.agro@gmail.com

Received: $11 / 2 / 2020$

Accepted: 12/4/2020.

\footnotetext{
${ }^{1}$ Departamento de Produção Vegetal, Universidade Estadual Paulista (UNESP) - 14884-900, Botucatu, São Paulo, Brasil.
}

${ }^{2}$ Universidade Federal Rural do Rio de Janeiro (UFRJ) - 23890-000, Seropédica, Rio de Janeiro, Brasil.

${ }^{3}$ Universidade de São Paulo (USP), Escola Superior de Agricultura "Luiz de Queiroz" - 13418-900, Piracicaba, São Paulo, Brasil. 


\section{INTRODUCTION}

Automated analysis of the physiological potential of seed lots leads to reduction in errors in interpretation, which increases the degree of reliability of the results of analysis. In this regard, computational resources have been and are currently used by researchers for seed analysis in studies involving different plant species (Onwinmol et al., 2016; Škrubej et al., 2015). From seed images obtained by cameras or scanners linked to a processor, it is possible to rapidly gather information with high accuracy (Trujillo et al., 2019). This information allows not only morphological studies of seeds (Jamil et al., 2017; Cervantes et al., 2016), but also physiological studies, especially through recording seedling performance (Marcos-Filho, 2015; Silva and Cicero, 2014a).

Computerized analysis of seedling images has been established as a powerful tool for measuring the performance of seed lots. This analysis makes multiple processing of seedling images possible, which allows parameters to be obtained that correlate with the physiological potential of seeds, as can be verified through use of the Seed Vigor Imaging System (SVIS ${ }^{\circledR}$ ) for soybean (Marcos-Filho et al., 2009), cucumber (Chiquito et al., 2012), carrot (Marchi and Cicero, 2017), and tomato (Ferreira et al., 2013) seeds.

In addition to seedling analysis, studies on seeds using computer images have been directed to performing tests on primary root emergence and determination of mean germination time for the purpose of differentiating seed lots regarding vigor (Matthews et al., 2012; Matthews and Powell, 2011). The advantage of these techniques consists of minimizing the subjectivity of interpretation, especially in relation to the result of analysis of primary root emergence. This is possible due to characterization of changes in the geometric dynamic of seeds through computer-assisted analysis, which can be correlated with physiological events that occur in seeds during the germination process. This procedure has potential for integration with traditional methods of evaluation of seed physiological quality (Wagner

et al., 2011; Dell'Aquila, 2009; Casco and Dias, 2008), generating a rapid and consistent response. Thus, the aim of this study was to verify the potential of using the test of primary root emergence in association with computational resources to determine tomato seed vigor.

\section{MATERIAL AND METHODS}

The study was carried out in the image analysis and seed analysis laboratories in the Crop Science Department of the Escola Superior de Agricultura "Luiz de Queiroz" (Esalq), at the Universidade de São Paulo (USP), using five tomato seed lots of the Roma cultivar. The seeds were disinfected through immersion in $30 \%$ sodium hypochlorite solution for $10 \mathrm{~s}$, followed by washing in distilled water. Before carrying out the experiment, the moisture content of the seeds from each lot was measured by the laboratory oven method at $105^{\circ} \mathrm{C}$ for 24 hours (Brasil, 2009). The physiological potential of the seeds was evaluated by the tests of germination, first germination count, seedling emergence in substrate, emergence speed index, computerized analysis of seedling images, and primary root emergence, together with computational resources, as described below.

Germination: four replications of 50 seeds were germinated in plastic boxes $(110 \times 110 \times 35 \mathrm{~mm})$ containing two sheets of germination paper moistened with distilled water in the amount of 2.5 times the dry weight of the paper at 20$30^{\circ} \mathrm{C}$, with a $6 / 18$ hour photoperiod. First germination count (FGC) occurred at five days after sowing, counting normal seedlings. The percentages of normal seedlings (germination percentage) were recorded on day 14 , as described in the Rules for Seed Testing (Brasil, 2009).

Seedling emergence (SE): four replications of 50 seeds were sown in polyethylene trays with organomineral substrate, moistened to field capacity. The percentage of emerged seedlings was calculated fourteen days after setting up the test, considering shoot growth of not less than $2 \mathrm{~mm}$ above the surface of the substrate as a criterion for seedling emergence.

Emergence speed index (ESI): evaluated together with the SE test, obtained by the ratio between the sum of the 
number of seedlings emerged for each day by the number of days that passed since sowing, according to the following formula: $\mathrm{ESI}=\sum \mathrm{En} / \mathrm{Nn}$ ( $\mathrm{En}=$ number of normal seedlings counted on the day; and $\mathrm{Nn}=$ number of days from sowing).

Computerized analysis of seedling images (SVIS ${ }^{\circledR}$ ): four replications of 25 seeds were germinated in a roll of germination paper moistened to 2.5 times its dry weight at $25{ }^{\circ} \mathrm{C}$ for four days. The seedling images were obtained with a scanner (HP Scanjet 200) adjusted to a resolution of 300 PPI and evaluated using the SVIS ${ }^{\circledR}$ to obtain seedling length (SL), hypocotyl length (HL), and primary root length (RL) (Silva and Cicero, 2014b).

Primary root emergence (RE) measured by means of computational resources: four replications of 25 seeds were germinated on germination paper fastened on a Petri dish containing $40 \mathrm{~mL}$ of water placed over an LED panel $(400 \times 400 \mathrm{~mm})$ to allow acquisition of images by transillumination. The images were obtained in the periods of $0,24,48,52,56$, and 60 hours with a digital camera (Logitech C920) connected to a computer. From the images obtained, seeds with primary root emergence were counted, and morphological parameters of aspect ratio and the area of each seed were determined using the Image ${ }^{\circledR}$ software (Cervantes et al., 2016). The aspect ratio represented the ratio between the largest and smallest diameter of the ellipse that circumscribes the seed (the greater the ratio, the more elongated the seed). A higher value of the ratio was associated with primary root emergence. The area represents the amount of two-dimensional space, i.e., the seed surface expressed in square millimeters. Expressive increase in the area value was associated with primary root emergence.

Statistical analysis: the trial was conducted in a completely randomized design (five seed lots with four replications). The normality of the data was tested by the Shapiro-Wilk test; and percentage data were transformed in arcsine $\sqrt{x} / 100$ when necessary. The factorial arrangement was used for evaluation of primary root emergence, aspect ratio, and seed area (five seed lots $\times$ six times). Sigmoidal fits were made for the data on primary root emergence, and polynomial fits were made for the data on aspect ratio and area. The mean values of the five seed lots were compared by the LSD test at $5 \%$, and Pearson correlations were tested for significance by Student's t-test at 5\%. The correlation coefficients were interpreted according to Zou et al. (2003).

\section{RESULTS AND DISCUSSION}

Germination (G) of the seed lots ranged from $78 \%$ to $98 \%$, and lots 2, 3, and 5 had normal seedling percentages greater than lots 1 and $4(p<0.05)$. The traditional method for evaluating tomato seed vigor made it possible to detect differences among the lots from evaluations of first germination count (FGC), seedling emergence (SE), and emergence speed index (ESI) ( $<<0.05$; Table 1). Lots 2, 4, and 5 gave rise to a greater percentage of normal seedlings in FGC compared to lots 1 and $3(p<0.05)$. The percentage of normal seedlings in the SE test in lots 3,4 , and 5 was superior to that in lot 1 . The emergence speed observed for lots 4 and 5 was superior to that obtained for lots 3,2 , and 1.

In recent years, determination of length of the seedling and of its parts has been an efficient approach for evaluating seed lot vigor. These evaluations have grown, due to the use of computational resources for capturing and processing seedling images in a rapid way, generating results with high precision and reliability (Santos et al., 2020; Castan et al., 2018). In the present study, computerized image analysis of seedlings at four days of age allowed identification of differences among seed lots regarding seedling length (SL), hypocotyl length (HL), and root length (RL) ( $p<0.05$; Table 1). Lots 2, 4, and 5 have SL, HL, and RL values superior to those observed for lots 1 and 3. Results of computerized analysis of five seedlings representative of lots 3 and 4 with individual and mean values of $S L, H L$, and $R L$ are shown in Figure 1 . The mean values of $S L, H L$, and $R L$ obtained for the five seedlings of lot 4 were superior to those obtained in lot 3 by $8.1 \mathrm{~mm}, 3.1 \mathrm{~mm}$, and $5.0 \mathrm{~mm}$, respectively. Furthermore, greater unevenness in development among the seedlings of lot 3 can be observed. For example, seedling 1 of this lot had a SL that was $47.6 \mathrm{~mm}$ less than seedling 5, whereas the greatest variation observed among the seedlings of lot 4 was $34.9 \mathrm{~mm}$. Although this also indicates lack of uniformity in seedling size, it occurred less frequently than in lot 3 . Based on these results, the sensitivity of computerized analysis of seedling images can be characterized to make distinctions in vigor among tomato seed lots, as previously reported for tomato seeds by Silva and Cicero (2014a). 
Thus, through traditional analyses and analyses of seedling length measured by SVIS ${ }^{\circledR}$, it was possible to stratify the lots regarding vigor (Table 1); this ensured that the lots analyzed had different potentials, a necessary condition to proceed with the study. After that, with the assistance of computational processing (Figure 2), it was possible to identify differences among the tomato seed lots based on primary root emergence (RE) ( $p<0.05$; Table 1 ). For most of the lots, stabilization of RE occurred 56 hours after the beginning of the test (Figure 3A). Lot 4 had a higher percentage of RE at the end of the test ( 60 hours) compared to the other lots. The percentages of RE obtained for lots 2 and 5 were superior to the percentages observed in lots 1 and 3 (Table 1). The test accompanying RE should be suspended at the period of 60 hours since proceeding with evaluations for stratification of the lots after that point is not possible, due to overlapping of the roots, making it difficult to obtain the individualized images necessary for identification of primary root emergence. The higher percentage of RE of lot 4 is due to its higher level of vigor, which results in greater capacity for initiating germination compared to lots of lower vigor, indicating greater sensitivity for separating lots regarding vigor by RE in relation to the traditional tests in tomato seeds (Table 1 ).

The morphological changes that occurred in the tomato seeds after primary root emergence were identified by the aspect ratio $(A R)(p<0.05$; Figure $3 B)$. The value of $A R$ corresponding to lot 4 was greater than the values observed in lots 2, 3, and 5 (Table 1). The lowest value of AR was found for lot 1 , corroborating with the lowest percentage of RE observed in that lot (Table 1). Changes in seed area were not very expressive, with an increase as of 24 hours after setting up the test. In evaluation of primary root emergence after 60 hours, lots 3 and 4 had a greater area than lot 2 $(\mathrm{p}<0.05 ;$ Table 1$)$.

From the results of RE percentage and AR at 60 hours after the beginning of the test, calculated with assistance of digital processing, it was possible to estimate the percentage of normal seedlings in the first germination count (FGC), percentage of seedling emergence (SE), emergence speed index (ESI), seedling length (SL), hypocotyl length (HL), and

Table 1. Physiological potential of seed lots of the Roma tomato cultivar through analysis of germination (G), first germination count (FGC), seedling emergence (SE), emergence speed index (ESI), seedling length (SL), hypocotyl length $(H L)$, root length $(R L)$, primary root emergence $(R E)$, aspect ratio $(A R)$ and seed area (Area).

\begin{tabular}{|c|c|c|c|c|c|c|c|c|c|c|}
\hline \multirow{3}{*}{ Seed lot } & \multicolumn{4}{|c|}{ Traditional tests } & \multicolumn{3}{|c|}{ Seedling growth } & \multicolumn{3}{|c|}{$\begin{array}{l}\text { Parameters of root emergence } \\
\qquad(60 \mathrm{~h})\end{array}$} \\
\hline & G & FGC & SE & \multirow{2}{*}{ ESI } & SL & $\mathrm{HL}$ & $\mathrm{RL}$ & $\mathrm{RE}$ & $\mathrm{AR}$ & Area \\
\hline & \multicolumn{3}{|c|}{---------- \% ---------- } & & \multicolumn{3}{|c|}{-------- cm -------- } & $\%$ & index & $\mathrm{mm}^{2}$ \\
\hline 1 & $78 \mathrm{~b}$ & $36 b$ & $91 \mathrm{~b}$ & $7.3 d$ & $53.7 \mathrm{~b}$ & $15.1 \mathrm{~b}$ & $38.6 \mathrm{~b}$ & $20 c$ & $1.28 \mathrm{c}$ & $7.2 \mathrm{ab}$ \\
\hline 2 & $96 a$ & $67 a$ & $95 a b$ & $8.3 \mathrm{c}$ & $66.1 \mathrm{a}$ & $18.8 \mathrm{a}$ & $47.3 \mathrm{a}$ & $55 b$ & $1.33 \mathrm{~b}$ & $6.6 \mathrm{~b}$ \\
\hline 3 & $95 \mathrm{a}$ & $40 \mathrm{~b}$ & 99 a & $9.0 \mathrm{~b}$ & $55.9 \mathrm{~b}$ & $16.7 \mathrm{~b}$ & $39.2 \mathrm{~b}$ & $21 \mathrm{c}$ & $1.31 \mathrm{~b}$ & $7.4 \mathrm{a}$ \\
\hline 4 & $88 \mathrm{~b}$ & $61 \mathrm{a}$ & 99 a & $9.5 \mathrm{a}$ & 65.9 a & $19.5 \mathrm{a}$ & $46.4 \mathrm{a}$ & $60 a$ & $1.37 \mathrm{a}$ & $7.5 \mathrm{a}$ \\
\hline 5 & $98 \mathrm{a}$ & $65 a$ & $98 \mathrm{a}$ & $9.2 \mathrm{a}$ & $68.0 \mathrm{a}$ & $20.2 \mathrm{a}$ & $47.8 \mathrm{a}$ & $52 b$ & $1.33 \mathrm{~b}$ & $6.8 \mathrm{ab}$ \\
\hline CV\% & 8.5 & 13.1 & 3.7 & 3.6 & 7.1 & 8.2 & 7.4 & 22.0 & 2.3 & 6.8 \\
\hline \multicolumn{11}{|c|}{ Correlation analyses } \\
\hline RE & $0.42^{\text {ns }}$ & $0.95^{*}$ & $0.36^{\text {ns }}$ & $0.53^{\text {ns }}$ & $0.96^{* *}$ & $0.91^{* *}$ & $0.96^{* *}$ & - & $0.88^{* *}$ & $-0.36^{\mathrm{ns}}$ \\
\hline$A R$ & $0.39^{\text {ns }}$ & $0.75^{*}$ & $0.66^{*}$ & $0.79^{*}$ & $0.79^{*}$ & $0.84^{* *}$ & $0.76^{*}$ & $0.88^{* *}$ & - & $0.07^{\text {ns }}$ \\
\hline Area & $-0.48^{\text {ns }}$ & $-0.59^{\text {ns }}$ & $0.24^{\text {ns }}$ & $0.27^{\mathrm{ns}}$ & $-0.51^{\mathrm{ns}}$ & $-0.36^{\mathrm{ns}}$ & $-0.56^{\mathrm{ns}}$ & $-0.36^{\mathrm{ns}}$ & $0.07^{\text {ns }}$ & - \\
\hline
\end{tabular}

Seed moisture content was $10 \pm 0.4$.

$\mathrm{CV} \%$ : coefficient of variation.

$*$ : significant at $5 \%(p<0.05)$.

**: significant at $1 \%(p<0.01)$ by the t-test.

n.s.: not significant.

Mean values followed by the same letter in the column do not differ from each other by the LSD test at $5 \%$ probability $(p<0.05)$. 
root length (RL) of the tomato seed lots due to the strong correlation between RE and FGC $(r=0.95 ; p<0.01), R E$ and $S L$ $(r=0.96 ; p<0.01)$, RE and HL $(r=0.91 ; p<0.01), R E$ and $R L(r=0.96 ; p<0.01)$, and AR and $H L(r=0.84 ; p<0.01) ;$ and moderate correlation between AR and FGC $(r=0.75 ; p<0.05)$, AR and ESI $(r=0.79 ; p<0.05)$, AR and SE $(r=0.66 ; p<$ $0.05), A R$ and $S L(r=0.79 ; p<0.05)$, and $A R$ and $R L(r=0.76 ; p<0.01)$ (Table 1). This result shows that determination of morphological attributes by digital processing can provide reliable information for evaluating the vigor of tomato seed lots. In seeds of this species, the characterization of primary root emergence has been indicated as a good parameter for rapidly estimating seed lot vigor, as reported by Ermis et al. (2015). Together with the results presented here, this reinforces the consistency of using this evaluation through digital processing to estimate the vigor of tomato seed lots, eliminating the subjectivity of interpretation inherent to an analyst.

Based on the correlation values obtained between AR and the other tests for measuring seed vigor, with moderate to strong variation $(r \geq 0.6)$, this calculation can be considered an efficient procedure for distinguishing the physiological potential of tomato seed lots (Table 1). Dell'Aquila et al. (2000) used image analysis and shape description techniques, such as seed area, and found high sensitivity and accuracy of this parameter in monitoring germination and identifying the time of primary root emergence of cabbage seeds. However, in the present study, changes in the area of the seeds during the germination process did not show correlation with the results of the traditional vigor tests (Table 1).

Size variations among seeds normally observed in commercial tomato seed lots can prevent the identification of some morphological changes associated with germination in the seeds. The tomato seeds used in the present study did not have $100 \%$ uniformity of size within the same seed lot (Figure 1). Thus, identification of lots with different vigor levels based on seed area as a parameter for characterizing primary root emergence was not efficient. To clarify why seed area was not an efficient variable, special focus was given to some seeds during digital processing (Figura 2), and this analysis leads to at least two main explanations: (i) when there are variations in size among the seeds of the sample, the value of seed surface area is different between individual seeds before primary root emergence (seed 1 versus seeds 5, 49, and 52; Figure 2) and after primary root emergence, as observed for seed 1 (without RE) versus seeds 8, 12, 20, and 60 (with

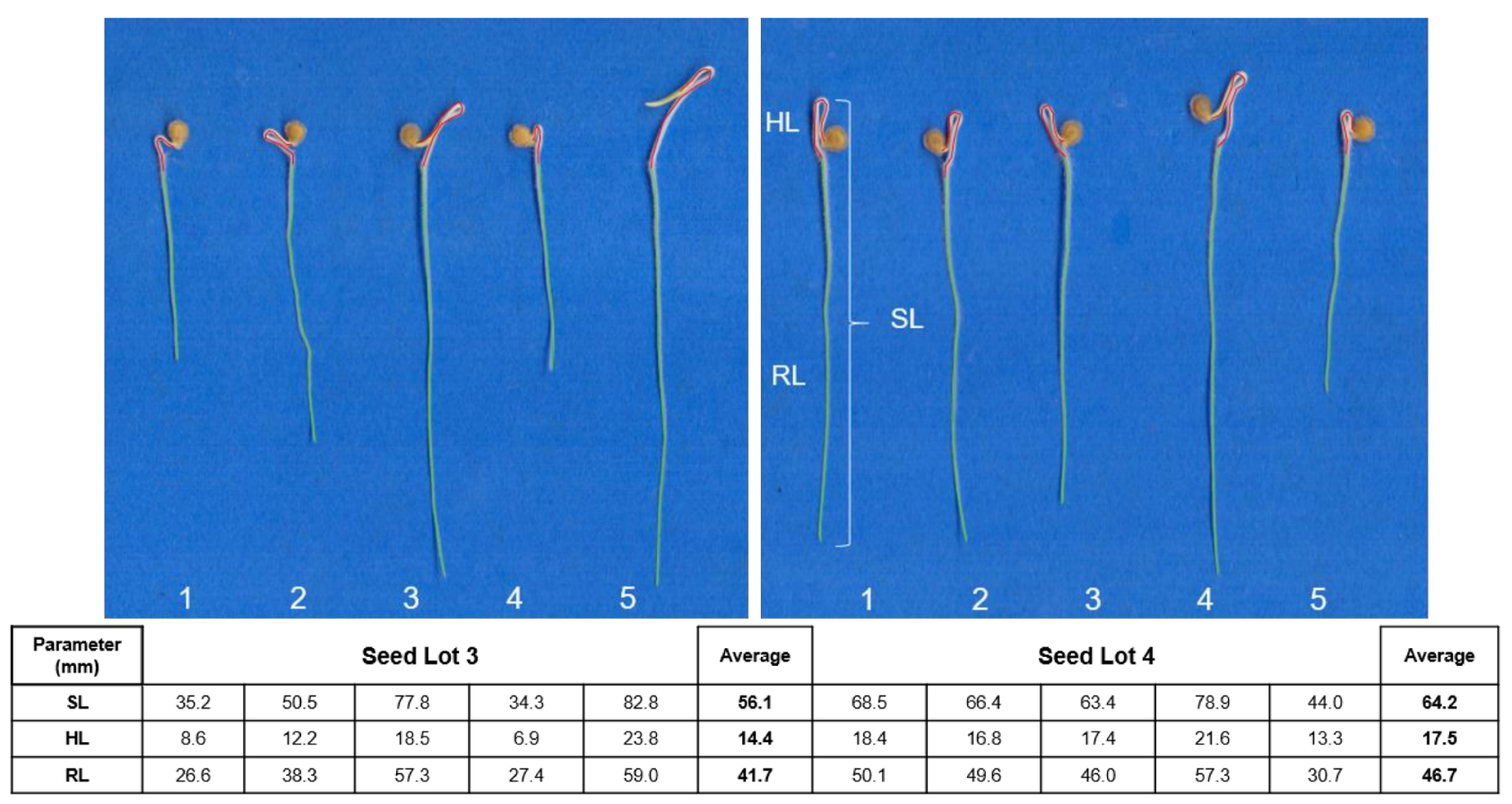

Figure 1. Computerized image analysis of tomato seedlings of lots 3 and 4. The parameters of seedling length (SL), hypocotyl length (HL), and root length (RL) were calculated with the assistance of the SVIS ${ }^{\circledR}$ software at $96 \mathrm{~h}$ after setting up the seed germination test at $25^{\circ} \mathrm{C}$. 
$\mathrm{RE}$ ); and (ii) seeds with the same area may have generated a primary root or not, as can be observed in seeds 39 and 60 (Figure 2). In addition, the seeds focused on that generated a primary root (green columns) had mean values for area similar to those of the seeds that did not generate a primary root (columns in yellow) (Figure 2). In contrast, determination of $A R$, whose values tend to increase when the primary root emerges and shows linear growth, allowed differences among seed lots with different vigor levels to be detected in a consistent manner. As AR expresses the ratio between the largest and smallest axis of the ellipse that circumscribes the seed, there is no interference of variations in the size of seeds on the accuracy of the results. However, for this determination to be reliable, it is important that the samples be placed within the germinator in a way that favors linear growth of the primary root.

Considering the potential of AR in stratification of vigor, a polynomial regression equation was fitted to this characteristic at 56 hours when stabilization of the RE occurred for most of the seed lots (Figure $3 \mathrm{~A}$ ), and the five seed lots were stratified regarding $A R$ in a range from $1.3398 \pm 0.011$ to $1.2438 \pm 0.008$ (Table 2). In spite of this narrow variation, the highest and lowest value of AR corresponded to lots 4 and 1, respectively, which were lots with contrasting vigor levels, according to the results shown in Table 1. This determination is important because the development of software to automate evaluation of root emergence will be able to use these equations for development of models. In addition, this aspect can be measured before finalization of the emergence test (in this study at 60 hours). The efficiency of determination of the percentage of primary root emergence had already been confirmed for evaluation of tomato seed vigor (Ermis et al., 2015). However, considering that computer-assisted image analysis has been one of the most popular approaches for automating evaluation of the physiological potential of seed lots (Dell'Aquila, 2007; Dell'Aquila, 2009), the results obtained in this study revealed AR as a morphological parameter consistent in characterization of primary root emergence of tomato seeds. Škrubej et al. (2015) also found that the computational system based on image processing is able to measure the events that encompass tomato seed germination with $95.44 \%$ accuracy, with potential for integration with the laboratory evaluations that are traditionally performed. In a similar manner, a study performed with Brassica napus seeds showed the effectiveness of computational image processing in ranking seed lot vigor levels, based on determination of primary root emergence (Matthews and Powell, 2011).

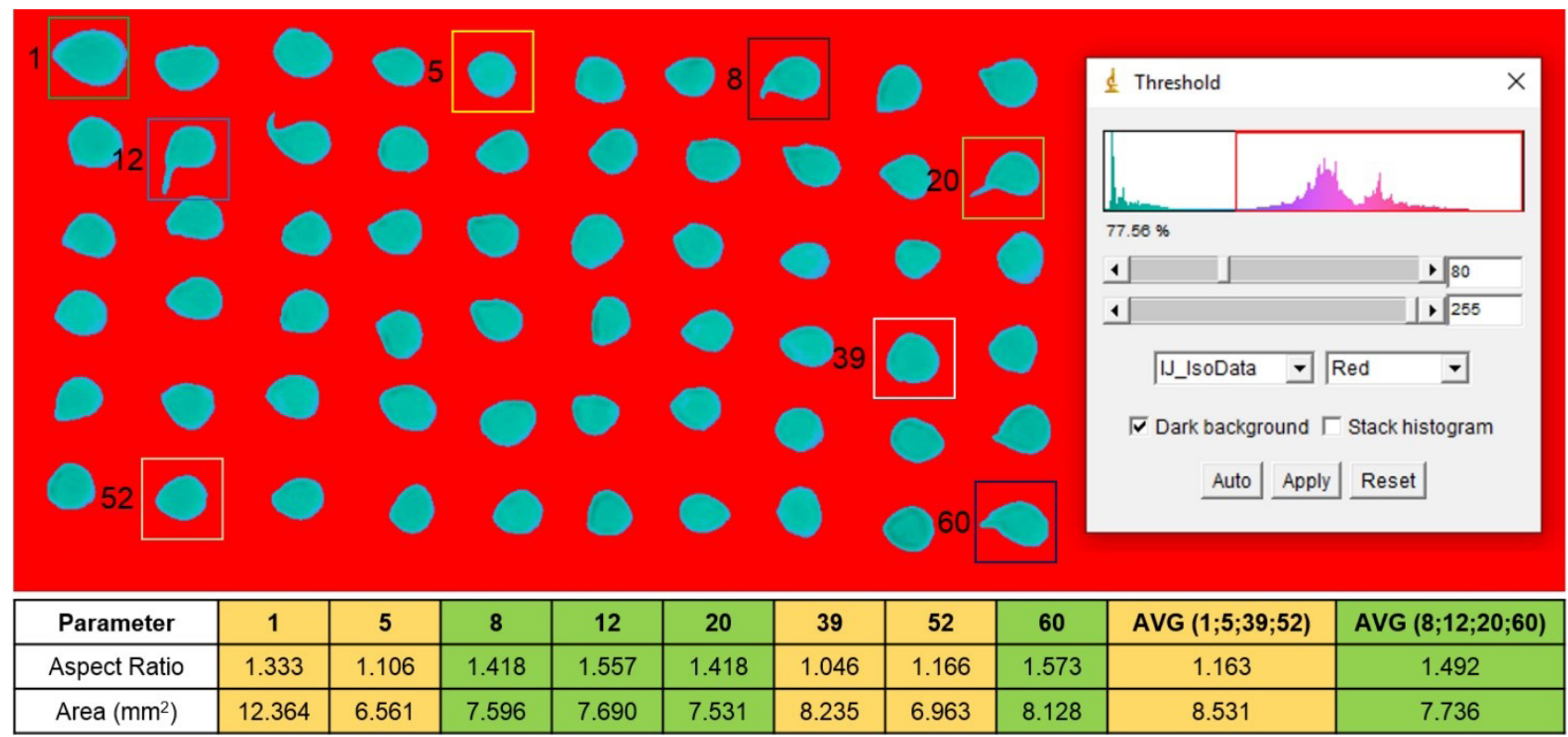

Figure 2. Images of tomato seeds from lot 3 processed by the Image ${ }^{\circledR}$ software focused on to exemplify the reasons for which the seed area variable was not efficient compared to the aspect ratio variable in characterizing primary root emergence. The parameters of aspect ratio and seed surface area colored in green and yellow correspond to the demarcated seeds from which a primary root emerged and did not emerge, respectively, at $56 \mathrm{~h}$ after setting up the germination test at $25^{\circ} \mathrm{C}$. 

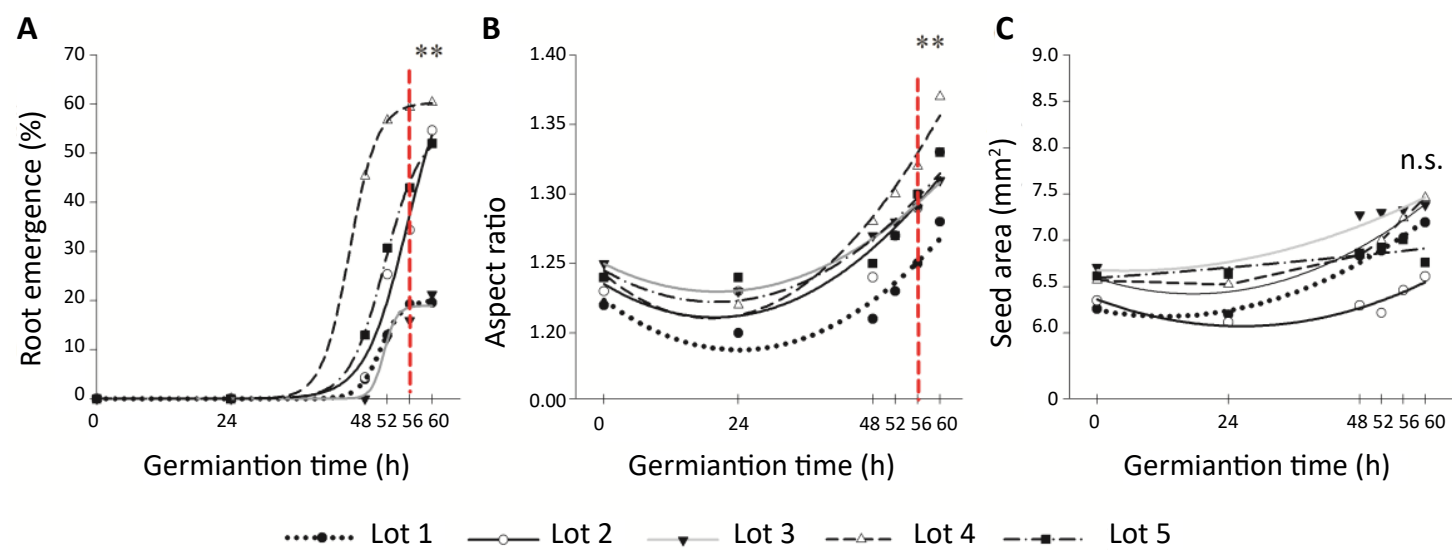

Figure 3. Primary root emergence (A) and morphological attributes of aspect ratio (B) and seed surface area (C) of five tomato seed lots, determined after digital image processing (Image ${ }^{\circledR}$ software) over the period of 60 hours after setting up the germination test at $25^{\circ} \mathrm{C}$. The vertical line at 56 hours in A and B indicates the time of maximum emergence of the primary root and aspect ratio, respectively, for most of the tomato seed lots. The symbols $\left({ }^{* *}\right)$ in $A$ and $B$ indicate significance at $1 \%$ of the models generated. In $C$, the regression models were not significant (n.s).

Table 2. Polynomial equations of the parameter of aspect ratio at the time of maximum emergence of the primary root of most of the tomato seed lots.

\begin{tabular}{cccc}
\hline Seed lot & Equation & $\begin{array}{c}\text { Time for emergence of } \\
\text { primary root }^{1}\end{array}$ & $\begin{array}{c}\text { AR at the time of } 56 \mathrm{~h} \\
\pm \text { standard deviation }\end{array}$ \\
\hline 1 & $0.000062 \mathrm{x}^{2}-0.0030 \mathrm{x}+1.22\left(\mathrm{R}^{2}=0.88\right)$ & $56 \mathrm{~h}$ & $1.2464 \pm 0.008$ \\
2 & $0.000062 \mathrm{x}^{2}-0.0025 \mathrm{x}+1.23\left(\mathrm{R}^{2}=0.85\right)$ & $56 \mathrm{~h}$ & $1.2844 \pm 0.009$ \\
3 & $0.000049 \mathrm{x}^{2}-0.0020 \mathrm{x}+1.25\left(\mathrm{R}^{2}=0.99\right)$ & $56 \mathrm{~h}$ & $1.2916 \pm 0.006$ \\
4 & $0.000087 \mathrm{x}^{2}-0.0033 \mathrm{x}+1.24\left(\mathrm{R}^{2}=0.97\right)$ & $56 \mathrm{~h}$ & $1.3280 \pm 0.011$ \\
5 & $0.000057 \mathrm{x}^{2}-0.0023 \mathrm{x}+1.25\left(\mathrm{R}^{2}=0.85\right)$ & $56 \mathrm{~h}$ & $1.2999 \pm 0.008$ \\
\hline
\end{tabular}

${ }^{1}$ The maximum time of root emergence of 56 hours was attributed to the value $x$ for each regression adjustment of the tomato seed lots.

Computer-assisted image analysis has been an important approach for automation of seed vigor evaluations. Thus, the definition of morphological parameters that reliably express the changes associated with seed germination, such as primary root emergence, is fundamental for supporting professionals involved with development of computational systems. This highlights the importance of the results reported in the present study.

\section{CONCLUSIONS}

Computational image processing based on the aspect ratio proved to be an efficient procedure for characterization of primary root emergence in evaluation of tomato seed vigor.

\section{ACKNOWLEDGMENTS}

Our thanks to the Fundação de Amparo à Pesquisa do Estado de São Paulo (FAPESP) (grant number 2015/24008-6 and 2018/13139-0). 


\section{REFERENCES}

BRASIL. Ministério da Agricultura, Pecuária e Abastecimento. Regras para análise de sementes. Ministério da Agricultura, Pecuária e Abastecimento. Secretaria de Defesa Agropecuária. Brasília: MAPA/ACS, 2009. 395p. https://www.gov.br/agricultura/pt-br/ assuntos/insumos-agropecuarios/arquivos-publicacoes-insumos/2946_regras_analise_sementes.pdf

CASCO, H.; DIAS, L.H. Estimating seed mass and volume from linear dimensions of seeds. Seed Science and Technology, v.36, n.1, p.230-236, 2008. https://doi.org/10.15258/sst.2008.36.1.28

CASTAN, D.O.C.; GOMES-JUNIOR, F.G.; MARCOS-FILHO, J.M. Vigor-S, a new system for evaluating the physiological potential of maize seeds. Scientia Agricola, v.75, n.2, p.167-172, 2018. https://doi.org/10.1590/1678-992x-2016-0401

CERVANTES, E.; MARTÍN, J.J.; SAADAOUI, E. Updated methods for seed shape analysis. Scientifica, v.2016, p.1-10, 2016. https://doi. $\operatorname{org} / 10.1155 / 2016 / 5691825$

CHIQUITO, A.A.; GOMES-JUNIOR, F.G.; MARCOS-FILHO, J. Assessment of physiological potential of cucumber seeds using the software Seedling Vigor Imaging System ${ }^{\circledR}$ (SVIS $\left.{ }^{\circledR}\right)$. Revista Brasileira de Sementes, v.34, n.2, p.255-263, 2012. http://dx.doi. org/10.1590/S0101-31222012000200010

DELL'AQUILA, A. Digital imaging information technology applied to seed germination testing. A review. Italian Journal of Agronomy, v.29, p.213-221, 2009. https://link.springer.com/article/10.1051/agro:2008039

DELL'AQUILA, A. Pepper seed germination assessed by combined X-radiography and computer-aided imaging analysis. Biologia Plantarum, v.51, n.4, p.777-781, 2007. https://link.springer.com/article/10.1007/s10535-007-0159-9

DELL'AQUILA, A.; VAN ECK, J.W.; VAN DER HEIJDEN, G.W.A.M. The application of image analysis in monitoring the imbibition process of white cabbage (Brassica oleracea L.) seeds. Seed Science Research, v.10, n.2, p.163-169, 2000. https://doi.org/10.1017/ S0960258500000179

ERMIS, S.; OZDEN, E.; DEMIR, I. Early radicle emergence count after controlled deterioration (CD) predicts emergence potential better than final standard germination after CD in tomato varieties. Seed Science and Technology, v.43, n.2, p.278-283, 2015. https://doi.org/10.15258/sst.2015.43.2.06

FERREIRA, R.L.; FORTI, V.A.; SILVA, V.N.; MELLO, S.C. Germination temperature in tomato seedlings performance. Ciência Rural, v.43, n.7, p.1189-1195, 2013. https://doi.org/10.1590/S0103-84782013000700008

JAMIL, M.; ALI, A.; GHAFOOR, A.; AKBAR, K.F.; NAPAR, A.A.; NAVEED, N.H.; YASIN, N.A.; GUL, A.; MUJEEB-KAZI, A. Digital image analysis of seed shape influenced by heat stress in diverse bread wheat germplasm. Pakistan Journal of Botany, v.49, n.4, p.12791284, 2017. https://www.pakbs.org/pjbot/papers/1502346999.pdf

MARCHI, J.L.; CICERO, S.M. Use of the software Seed Vigor Imaging System (SVIS ${ }^{\circledR}$ ) for assessing vigor of carrot seeds. Scientia Agricola, v.74, n.6, p.469-473, 2017. https://doi.org/10.1590/1678-992x-2016-0220

MARCOS-FILHO, J. Seed vigor testing: an overview of the past, present and future perspective. Scientia Agricola, v.72, n.4, p.363374, 2015. https://doi.org/10.1590/0103-9016-2015-0007

MARCOS-FILHO, J.; KIKUTI, A.L.P.; LIMA, L.B. Métodos para avaliação do vigor de sementes de soja, incluindo análise computadorizada de imagens. Revista Brasileira de Sementes, v.31, n.1, p.102-112, 2009. https://doi.org/10.1590/S0101-31222009000100012

MATTHEWS, S.; NOLI, E.; DEMIR, I.; KHAJEH-HOSSEINI, M.; WAGNER, M.H. Evaluation of seed quality: from physiology to international standardization. Seed Science and Technology, v.22, s.1, p.69-73, 2012. https://doi.org/10.1017/S0960258511000365

MATTHEWS, S.; POWELL, A.A. Towards automated single counts of radicle emergence to predict seed and seedling vigour. Seed Testing International, n.142, p.44-48, 2011. https://www.seedtest.org/upload/cms/user/STI14244-48.pdf

ONWINMOL, D.; CHANMPRASERT, W.; CHANGSEE, P.; RONGSANGCHAICHAREON, T. Seed vigor classification using analysis of mean radicle emergence time and single counts of radicle emergence in rice (Oryza sativa L.) and mung bean (Vigna radiata (L.) Wilczek). Agriculture and Natural Resources, v.50, n.5, p.345-350, 2016. https://doi.org/10.1016/j.anres.2016.12.003

SANTOS, R.F.; GOMES-JUNIOR, F.G.; MARCOS-FILHO, J. Morphological and physiological changes during maturation of okra seeds evaluated through image analysis. Scientia Agricola, v.77, n.3, p.1-9, 2020. https://doi.org/10.1590/1678-992x-2018-0297

Journal of Seed Science, v.43, e202143005, 2021 
ŠKRUBEJ, U.; ROZMAN, C.; STAJNKO, D. Assessment of germination rate of the tomato seeds using image processing and machine learning. European Journal of Horticultural Science, v.80, n.2, p.68-75, 2015. https://doi.org/10.17660/eJHS.2015/80.2.4

SILVA, V.N.; CICERO, C.M. Análise de imagens de plântulas para avaliação do potencial fisiológico de sementes de berinjela. Horticultura Brasileira, v.32, n.2, p.145-151, 2014a. https://doi.org/10.1590/S0102-05362014000200004

SILVA, V.N.; CICERO, C.M. Análise de imagens de plântulas para avaliação do potencial fisiológico de sementes de tomate. Revista Ciência Agronômica, v.45, n.2, p.327-334, 2014b. https://doi.org/10.1590/S1806-66902014000200014

TRUJILLO, H.A.; GOMES-JUNIOR, F.G.; CICERO, S.M. Digital images of seedling for evaluating coffee seeds. Journal of Seed Science, v.41, n.1, p.60-68, 2019. https://doi.org/10.1590/2317-1545v41n1204651

WAGNER, M.H.; DEMILLY, D.; DUCOURNAU, S.; DURR, C.; LÉCHAPPÉ, J. Computer vision for monitoring seed germination from dry state to young seedlings. Seed Testing International, n.142, 2011. https://www.seedtest.org/upload/cms/user/STI14249-51.pdf

ZOU, K.H.; TUNCALI, K.; SILVERMAN, S.G. Correlation and simple linear regression. Radiology, v.227, n.3, p.617-628, 2003. https:// doi.org/10.1148/radiol.2273011499 use, distribution, and reproduction in any medium, provided the original work is properly cited. 